\title{
Left atrial papillary fibroelastoma as an unusual cause of myocardial infarction
}

\author{
Farhad Waziri, Erik Lerkevang Grove
}

Department of Cardiology, Aarhus University Hospital, Skejby, Aarhus, Denmark

\section{Correspondence to} Dr Erik Lerkevang Grove, erikgrove@dadlnet.dk

Accepted 18 August 2014

\section{DESCRIPTION}

A 70-year-old woman with no history of cardiac disease was admitted with sudden onset of chest pain. ECG was normal. On infusion of nitroglycerin up to $16 \mathrm{~mL} / \mathrm{L}$, the patient became pain free. Bedside transthoracic echo showed discrete hypokinesia in the apicolateral region of the left ventricle and a possible thrombus in the left atrium. Cardiac markers (troponin $\mathrm{T}$ and creatine kinase $\mathrm{MB}$ ) were elevated. Coronary angiography was normal with the exception of a minor side vessel occlusion, and CT showed no sign of pulmonary embolism. Transoesophageal echo showed a $0.9 \times 1.5 \mathrm{~cm}$ pedunculated structure in the left atrium (video 1 and figure 1). MRI of the heart showed late enhancement (gadolinium) with microvascular obstruction in the left ventricle and reinforced the suspicion of myxoma in the left atrium (video 2). Surgical excision of the tumour was successfully performed and histological examination revealed a papillary fibroelastoma.

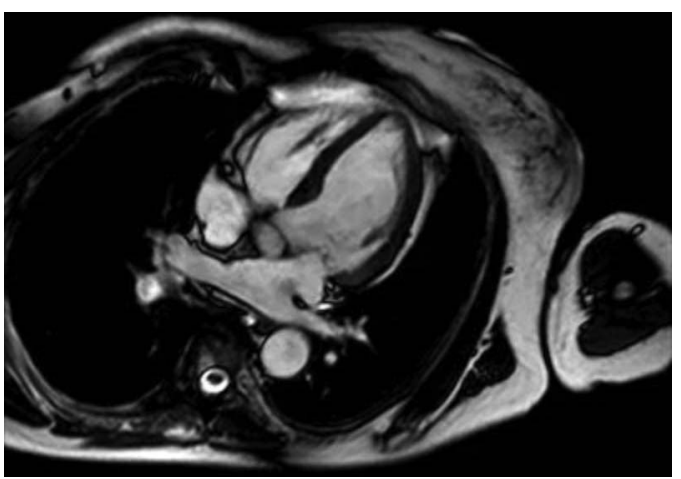

Video 1 Transoesophageal echocardiography of pedunculated structure between the left atrial appendage and the left upper pulmonary vein.

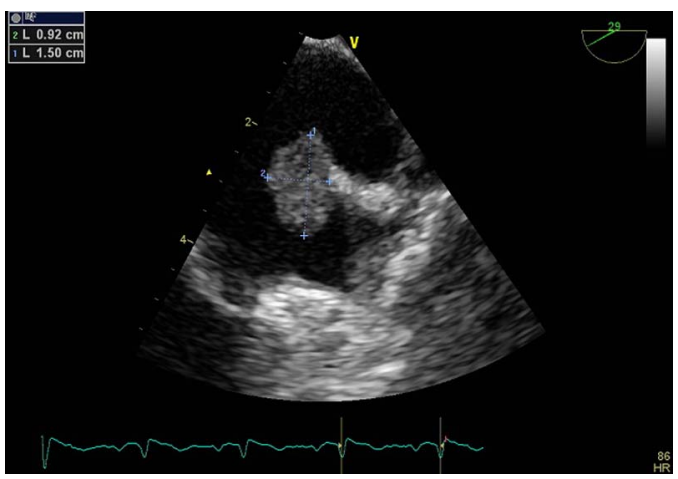

Figure 1 Transoesophageal echocardiography showing the size of the structure in the left atrium.

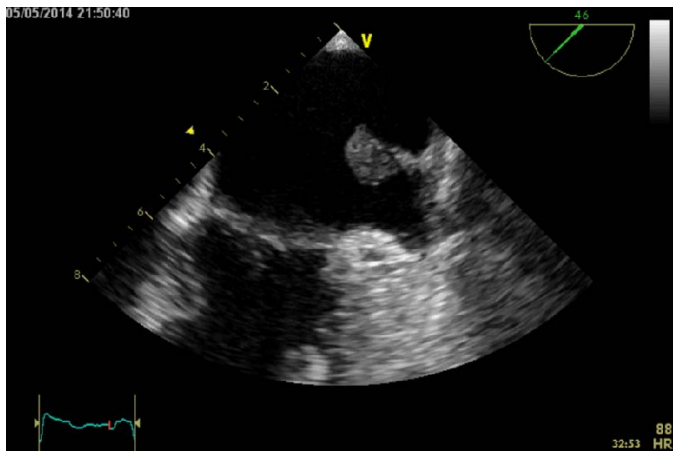

Video 2 Magnetic resonance imaging of pedunculated structure between the left atrial appendage and the left upper pulmonary vein.

Primary cardiac tumours are extremely rare $(0.02 \%$ of autopsies $),{ }^{1}$ whereas metastasic involvement of the heart is 20 times more common. ${ }^{2}$ Papillary fibroelastoma is the second most common primary cardiac tumour found in adults. ${ }^{1}$ Cardiac tumours may be symptomatic or found incidentally. Signs and symptoms of cardiac tumours are generally determined by their location and not by the histopathology. ${ }^{3}$ More than $80 \%$ of fibroelastomas are located on the heart valves, few in the ventricles and even less in the left atrium (1.6\%). ${ }^{1}$ Primary cardiac tumours are extremely rare causes of ischaemic cardiovascular events.

\section{Learning points}

- Cardiac tumours are rare causes of ischaemic cardiovascular events.

- Transoesophageal echocardiography provides high diagnostic certainty in patients with cardiac papillary fibroelastomas and reliably identifies atypical locations of these tumours on non-valvular surfaces.

- The type of cardiac tumours is generally determined by the location of the tumour, but definitive classification is given by histopathological examination.

Contributors FW and ELG collected the patient data (picture, videos and patient history). FW wrote the initial draft and ELG critically revised the manuscript. Both authors approved the final version.

Competing interests None.

Patient consent Obtained.

Provenance and peer review Not commissioned; externally peer reviewed. 


\section{REFERENCES}

1 Gowda RM, Khan IA, Nair CK, et al. Cardiac papillary fibroelastoma: a comprehensive analysis of 725 cases. Am Heart J 2003;146: 404-10.
2 Silvestri F, Bussani R, Pavletic N, et al. Metastases of the heart and pericardium. G Ital Cardiol 1997;27:1252-5.

3 Vander Salm TJ. Unusual primary tumors of the heart. Semin Thorac Cardiovasc Surg 2000;12:89-100.

Copyright 2014 BMJ Publishing Group. All rights reserved. For permission to reuse any of this content visit

http://group.bmj.com/group/rights-licensing/permissions.

BMJ Case Report Fellows may re-use this article for personal use and teaching without any further permission.

Become a Fellow of BMJ Case Reports today and you can:

- Submit as many cases as you like

- Enjoy fast sympathetic peer review and rapid publication of accepted articles

- Access all the published articles

- Re-use any of the published material for personal use and teaching without further permission

For information on Institutional Fellowships contact consortiasales@bmjgroup.com

Visit casereports.bmj.com for more articles like this and to become a Fellow 